\title{
Petrography and major element chemistry of the volcanic rocks of the Andes, southern Peru
}

\author{
Shigeo Aramaki, ${ }^{1}$ NaOKI Onuma ${ }^{2}$ and Felix Portillo ${ }^{3}$ \\ Earthquake Research Institute, University of Tokyo, Bunkyo-ku, Tokyo $113,{ }^{1}$ \\ Department of Earth Sciences, Ibaraki University, Mito $310^{2}$ and \\ Institu to Geologica Minero y Metalurgico, Lima, Peru ${ }^{3}$
}

(Received December 12, 1983: Accepted May 29, 1984)

\begin{abstract}
More than 200 samples of late Tertiary to Quaternary volcanic rocks have been collected from the northern sector of the central volcanic zone of the Andean belt occupying southern Peru. The most abundant rock type is the pyroxene andesite. Many of the rock samples carry hornblende and/or biotite phenocrysts. Small amounts of shoshonites occur on the back arc side near Puna and Siquani and olivine-augite basanites occur on the western shore of Lake Titicaca. The $\mathrm{SiO}_{2}$ frequency has a mode in the $60-65 \%$ range which is about $5 \%$ higher than the Quaternary volcanic rocks of Japan. The $\mathrm{K}_{2} \mathrm{O}$ content shows a distinct tendency to increase away from the front, while the $\mathrm{Na}_{2} \mathrm{O}$ content tends to decrease in the same direction.

The K, Sr and Ba contents of the late Tertiary to Quaternary volcanic rocks of the northern part of the central zone of the Andean volcanic belt (southern Peru) show regular increase away from the volcanic front. At the same time, a slight northwestward increase along the arc is detected. The Na content regularly decreases away from the front making a strong contrast to the Japanese Quaternary volcanic arcs, which does not show any regular change. The $\mathrm{Na}$ content is conspicuously higher in the northwestern frontal zone than the rest.
\end{abstract}

\section{INTRODUCTION}

A cooperative project on the geochemical study of central Andean volcanic zone was carried out during the period from May, 1980 through March, 1982, including the field work and laboratory analyses. The project was cosponsored by the Overseas Scientific Research, Ministry of Education (Mombusho) of Japan and Instituto Geologico Minero y Metalurgico (INGEMMET) of Peru. The Japanese research group consisted of N. ONuma (Project leader, Department of Earth Sciences, Ibaraki University, trace element geochemistry), $S$. ARAMAKI (Earthquake Research Institute, University of Tokyo, geology and major element geochemistry), K. Notsu (Institute of Chemistry, University of Tsukuba, $\mathrm{Sr}$ isotope geochemistry), I. K ANEOKA (Geophysical Institute, University of Tokyo, K-Ar dating), A. HASEGAWA (Observation Center for Earthquake
Prediction, Tohoku University, seismology) and N. FUתI (Department of Earth Sciences, Kobe University, volcano physics). The Peruvian research group consisted of the staff of INGEMMET, C. Guevara (Chief, Geology section), F. Portillo (geology), M. Montoya (geology) and J. A. Lajo (geology).

Our objective was to elucidate the processes of generation and evolution of the magma formed through the chemical interactions between the subducting Nazca plate and the mantle at depths on the basis of the geochemical studies of Andean andesties in the central Andes volcanic belt (southern Peru) where volcanism is taking place over the crust which is the thickest (about $70 \mathrm{~km}$ ) in the world.

The main field work took place in the summer of 1980 for about 70 days and the area covered ranged from $14^{\circ} \mathrm{S}$ to $18^{\circ} \mathrm{S}$ crossing the whole width of the Andean volcanic belt (Fig. 1). The area is located at the northernmost 
sector of the central zone of the Andean volcanic belt which overlies the Nazca plate subducting eastward, and corresponds to a transition zone between the normal- and abnormal subduction segments of the Nazca plate (HASEGAWA and SACKS, 1981). The northern limit of the central zone roughly corresponds to the northern limit of the part of the Nazca plate subducting at an angle of about 30 degrees (normal subduction). To the north of this, the Nazca plate dips at about 30 degrees for the first $100 \mathrm{~km}$ of the descent from the trench, but remains nearly horizontal for the next $300 \mathrm{~km}$ and then dips again at about 30 degrees (abnormal subduction). The horizontal portion roughly corresponds to the northern extension of the central volcanic zone. The virtual absence of the young volcanic activity in this area may be due to the shallow depth of the subducting Nazca plate and the very thick (about $70 \mathrm{~km}$, Cummings and Schiller, 1971) crust acting together to restrict the amount of the asthenosphere edge below this area (HASEgAwA and SACKS, in preparation).

This report is one of a series of papers resulting from the current project and deals with the summary of petrography, major element geochemistry and chemical mapping of the volcanic rocks.

Abundant volcanic centers and volcanic materials occur in the studied area spanning in age from early Tertiary to historic time. Stratigraphy has been extensively studied by the INGEMMET scientists but radiometric dating has been so far very limited (KANEOKA and GuevarA, 1984). Therefore one of the main difficulties in characterizing the Andean volcanism in comparison with more well-defined volcanic arcs such as those in the Japanese islands is to distinguish the spatial variation of the volcanic materials from the temporal one.

Major and minor element data published by LEFÈvRE $(1973,1979)$ cover the southern half of the area of the present study. He demonstrated a clear tendency of increasing $\mathrm{K}$ content away from the volcanic front but his results also cannot escape from the temporal con- straints stated above.

\section{SAmple Collection}

Selection of the sampling locality depended totally on the extensive information already collected by INGEMMET, Peru. Based on the published and unpublished geologic quadrangle maps and reports, sites were selected for the representative Quaternary volcanic suites in southern Peru. In principle, rocks designated as Barroso group (see KANEOKa and Guevara, 1984, Fig. 2) were our main target while those of the Senca and Tacaza were excluded. It was hoped that by restricting the geologic age

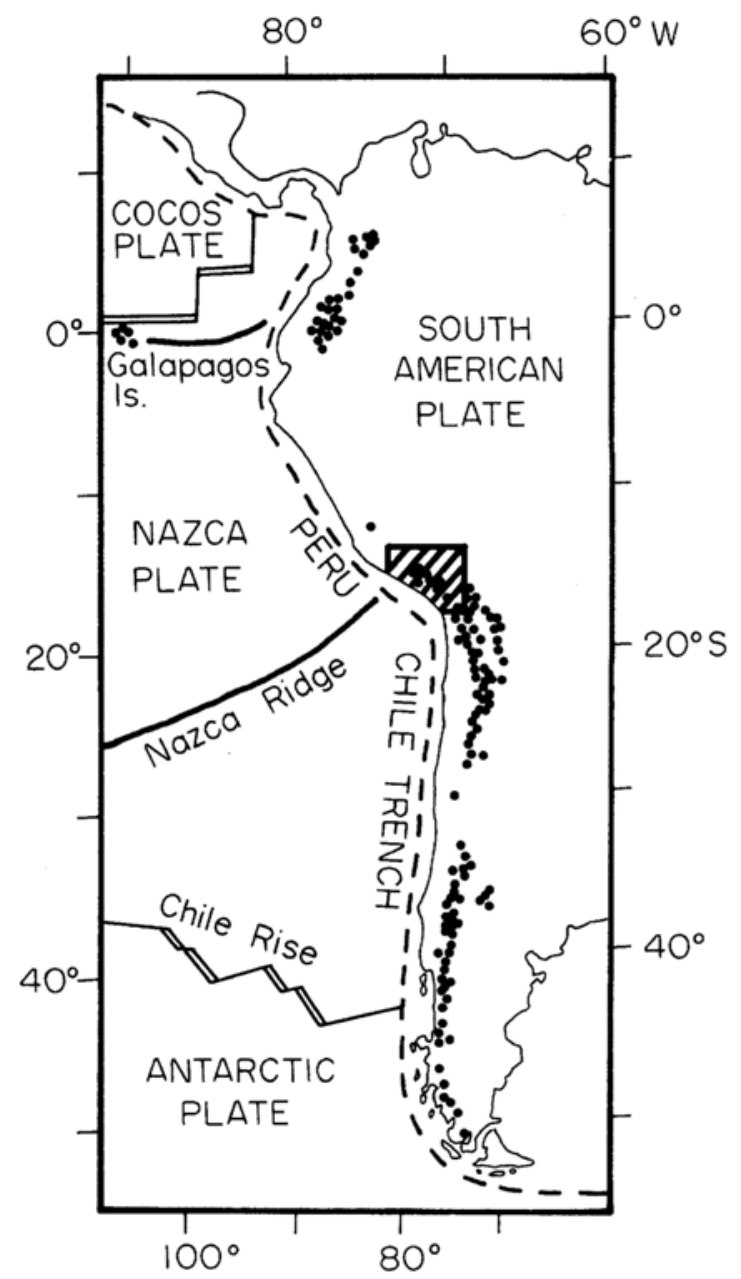

Fig. 1. Index map of the Andean volcanic belt. Dots indicate the distribution of the Quaternary volcanoes. Obliquely ruled area corresponds to Fig. 2. 


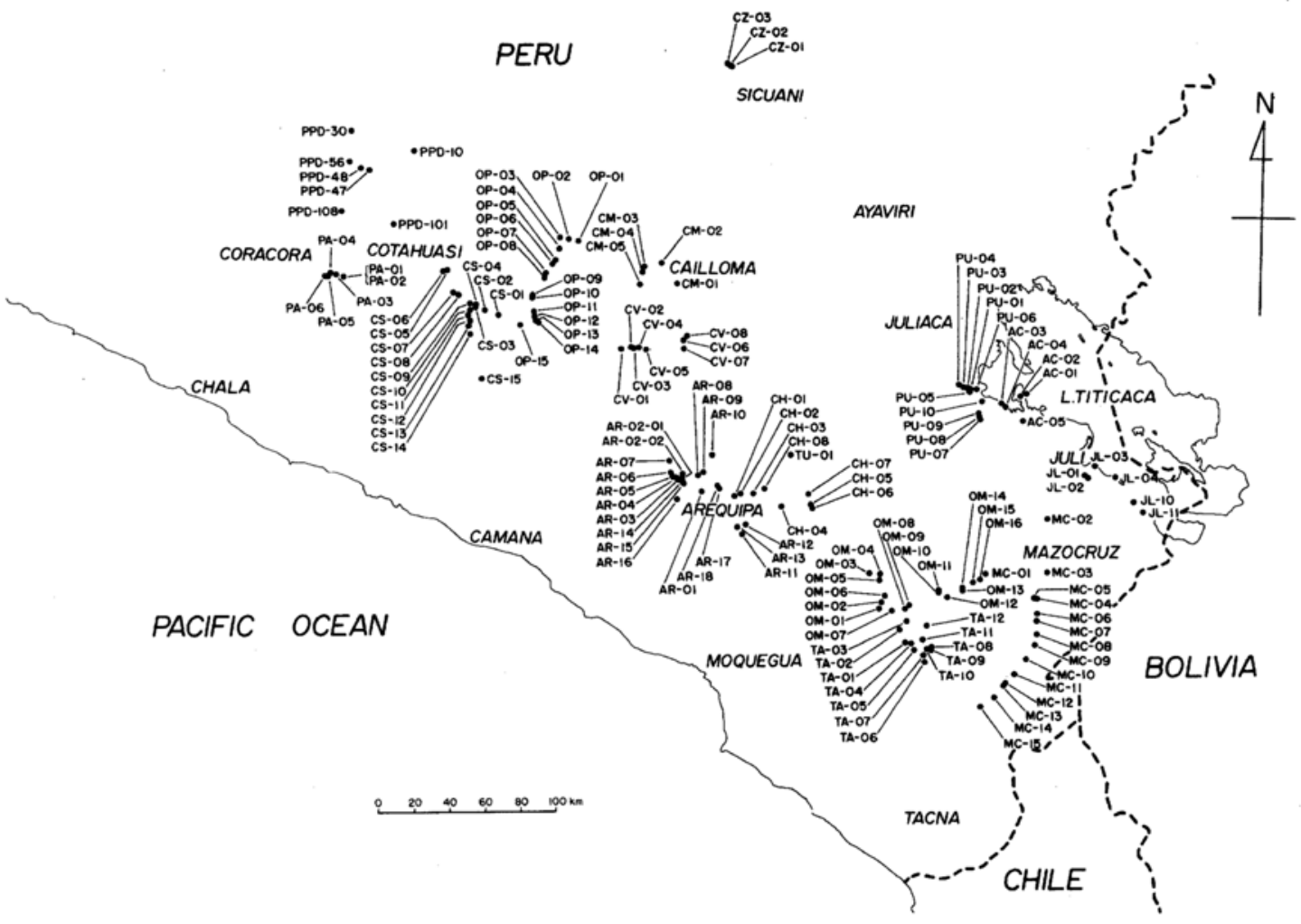

Fig. 2. Map showing the locality of the sample. Numbers refer to Appendices 1 and 2.

of the samples as close as possible, the spatial characterization of the magma chemistry may be best achieved.

During the field work, the impression of one of the authors (S.A.) who has an intimate acquaintance with wet and temperate environments of Japanese islands but is quite unfamiliar with the arid environment of Altiplano, was the difficulty of assessing the age of the volcanic edifices from their state of erosion. For example, inspections of aerial photographs gave us a very young age estimate (say less than several tens of thousand years) of the pyroclastic cones and lava flows of the Orcopampa region because of their apparent freshness and lack of gullys etc. which are indicative of stream erosion. In the field it was apparent that the rocks are much weathered, microtopography showing significant mass wasting and indicating appreciably older age than our first estimates.

Localities of sampling are shown in Fig. 2 and listed in Appendix 1. Total number of samples was over 200 . The most recent materials apparently form snow-clad high peaks and it was impossible to cover them in the limited time of our expedition. One of the youngest samples we were able to collect was from a block lava flow issuing from Nevado Coropuna southwestwards (CS-12). This lava may very well be a historic flow. Block lava flows in the Siquani region (CZ-01 through CZ-03) dated by KANEOKa and Guevara (1984) as <0.027 Ma show a very fresh topography and undoubtedly are among the youngest of all the volcanic products in southern Peru.

\section{Microscopic PETROGRaPHY}

Under the microscope, about $82 \%$ of the total samples may be named andesite and about $10 \%$ dacite or rhyolite. Ten samples were named shoshonite (PU-01 through PU-06, and CZ-01, $-02,-03)$, following the nomenclature of LEFÈvRE (1973, 1979), and three (AC-01, -02, 
-03) basanite. A good proportion of such andesites may be classified as dacites from high $\mathrm{SiO}_{2}$ contents as revealed from chemical analyses although it was difficult to distinguish dacites from andesites under the microscope. If chemical scheme of nomenclature is strictly applied, some other "andesitic" rocks like MC01, MC-03, MC-06 etc. should be called shoshonite or banakite. A list of detailed microscopic petrography of all the thin sections may be available from the authors upon request.

Basanites occurring in a small peninsula on the southern shore of Titicaca Lake (AC-01, AC02) contains abundant fresh olivine phenocrysts, no plagioclase, and K-feldspar and nepheline (or zeolite?) in the groundmass. They contain more than $6 \%$ of normative nepheline and $\mathrm{K}_{2} \mathrm{O}$ / $\mathrm{Na}_{2} \mathrm{O}=1.4$. Sample AC-03 is probably similar in petrography.

Assemblage of phenocrysts is shown in Table 1. Totally aphyric lavas comprise about $7 \%$ of our collection and $17 \%$ lack plagioclase phenocrysts. The assemblage clinopyroxeneorthopyroxene-hornblende (and magnetite) phenocryst is the most abundant $(15 \%)$ and the rocks with clinopyroxene + orthopyroxene phenocrysts make up $36 \%$ of the total. Hornblende without biotite occurs in $33 \%$ and hornblende with biotite occurs in $22 \%$ of the rocks. In other words, hornblende occurs in $55 \%$ of the rocks and biotite in $35 \%$.

\section{Major Element Chemistry}

XRF analysis was made on 10 major oxides using Geigerflex IKF-3064 at the Geological Institute, University of Tokyo. Powdered samples were fused with $\mathrm{LiBO}_{4}$ flux into glass tablets (1 to 5 dilution) and the measured intensities were corrected according to the procedure described by MATSUMOTO and URABE (1980). Results are given in Appendix 2. The sum of the 10 oxides is made $100 \%$.

All of the 87 samples analyzed except one carry normative quartz. The only exception is the basanite mentioned earlier (AC-01) with $6.9 \%$ nepheline making a strong contrast with other rocks in the region. In Table 2, frequency in $\mathrm{SiO}_{2}$ wt\% is compared with LEFÈVRE'S data (LEFÈvre, 1973). The two match closely and show a mode in $60-65 \% \mathrm{SiO}_{2}$ range (Fig. 3). When compared with the whole Japanese Quaternary volcanic rocks (ARAMAKI and UI, 1978), southern Peruvian suite gives a sharper peak than the Japanese ones with an average shifting by about $5 \%$ toward the high $\mathrm{SiO}_{2}$ side.

Some of the Harker variation diagrams are shown in Figs. 4 through 7 . The samples are geographically subdivided into two parallel zones running along the arc: (1) the zone along the volcanic front and (2) the northeastern zone adjacent to (1). The most striking contrast is

Table 1. Phenocryst assemblage of the volcanic rocks of southern Peru. Numbers in parentheses indicate those rocks without plagioclase phenocrysts

\begin{tabular}{lrcrc}
\hline & NONE & Hornblende & $\begin{array}{c}\text { Hornblende } \\
\text { + biotite }\end{array}$ & Biotite \\
$\begin{array}{l}\text { Olivine } \\
\begin{array}{l}\text { Olivine }+ \\
\text { clinopyroxene }\end{array}\end{array}$ & $3(1)$ & $2(1)$ & & \\
$\begin{array}{l}\text { Olivine }+ \\
\text { clinopyroxene }+ \\
\text { orthopyroxene }\end{array}$ & $11(3)$ & $1(1)$ & $1(0)$ & $3(0)$ \\
$\begin{array}{l}\text { Clinopyroxene }+ \\
\text { orthopyroxene }\end{array}$ & $14(1)$ & $25(0)$ & $12(0)$ & $10(0)$ \\
$\begin{array}{l}\text { Orthopyroxene } \\
\text { NONE }\end{array}$ & $1(0)$ & $10(0)$ & $5(0)$ & $1(0)$ \\
$\begin{array}{l}\text { Clinopyroxene } \\
\text { Olivine }+\end{array}$ & $17(2)$ & $7(3)$ & $13(0)$ & $7(2)$ \\
orthopyroxene & $2(0)$ & $8(3)$ & $5(0)$ & $1(0)$ \\
\hline
\end{tabular}


in the $\mathrm{K}_{2} \mathrm{O}$ content which increases away from the front (Fig. 4). When compared with the Quaternary Japanese islands, the least potassic trend in sothern Peru is more potassic than the most potassic trend in the Japanese islands. To the contrary, while the Japanese rocks do not show appreciable difference in the $\mathrm{Na}_{2} \mathrm{O}$ levels (Fig. 5), the rocks of the frontal zone (symbol + in Fig. 5) of southern Peru is definitely richer in $\mathrm{Na}_{2} \mathrm{O}$ than the inland zone (symbol o). The general constancy of the $\mathrm{Na}_{2} \mathrm{O}$ contents with varying $\mathrm{SiO}_{2}$ contents holds both for Japan and southern Peru.
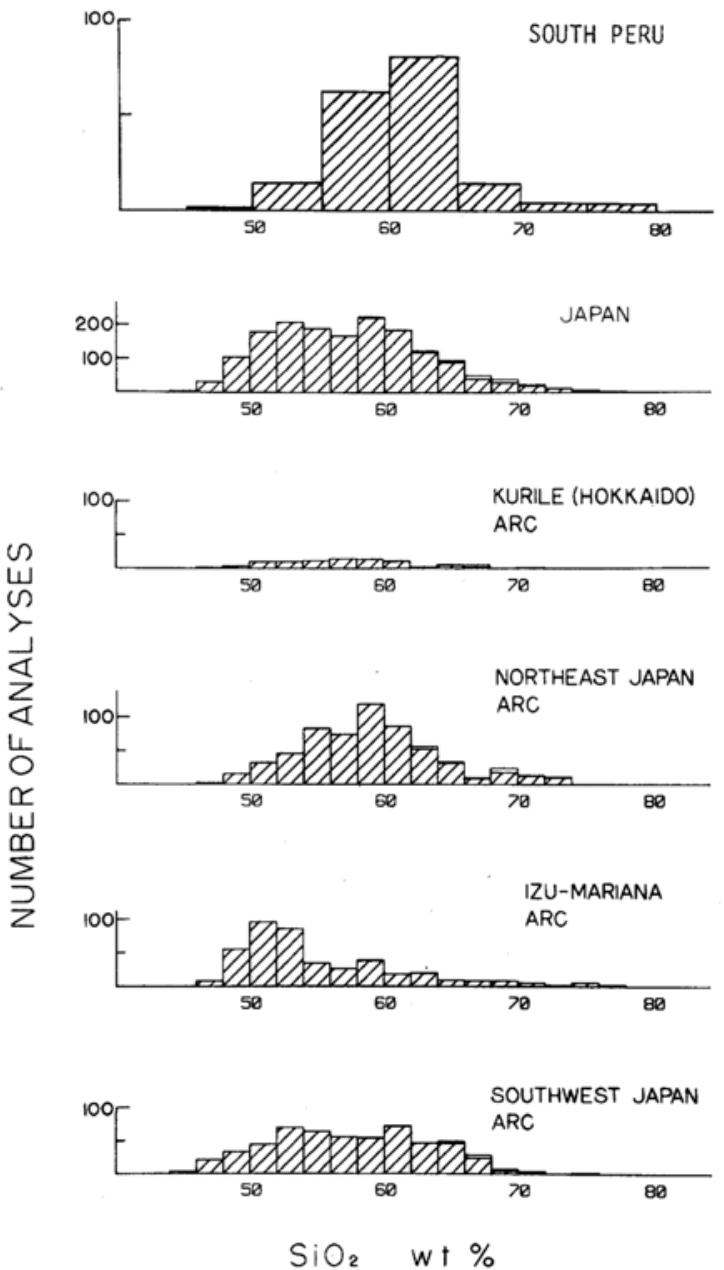

Fig. 3. Frequency distribution of $\mathrm{SiO}_{2}$ contents of the volcanic rocks in southern Peru (top), compared with those of the Japanese Quaternary volcanic rocks (ARAMAKI and UI, 1978).
Table 2. Frequency distribution of $\mathrm{SiO}_{2}$ contents

\begin{tabular}{ccc}
\hline $\begin{array}{c}\text { Number of } \\
\text { analyses }\end{array}$ & This report & LEFÈVRE (1973) \\
$\% \mathrm{SiO}_{2}$ & & \\
$>75$ & 1 & 2 \\
$75-70$ & 2 & 1 \\
$70-65$ & 8 & 4 \\
$65-60$ & 39 & 38 \\
$60-55$ & 31 & 31 \\
$55-50$ & 5 & 7 \\
$50>$ & 1 & 0 \\
\hline
\end{tabular}

$\mathrm{Al}$ and $\mathrm{Ca}$ are the only remaining major elements which show some detectable zonation in composition across the arc (Figs. 6 and 7). The general level of $\mathrm{Al}_{2} \mathrm{O}_{3}$ and $\mathrm{CaO}$ is higher in the frontal zone (1) as compared with the inland zone (2). In the frontal zone, the $\mathrm{Al}_{2} \mathrm{O}_{3}$ content monotonously decreases with increasing $\mathrm{SiO}_{2}$ content in the range of 50 to $70 \%$ while in the inland zone, it increases in the $\mathrm{SiO}_{2}$ compositional range of 45 to $60 \%$ (Fig. 6). $\mathrm{CaO}$ content decreases monotonously with $\mathrm{SiO}_{2}$ content in both zones (Fig. 7). This indicates that the compositional variations of $\mathrm{Al}_{2} \mathrm{O}_{3}$ and $\mathrm{CaO}$ are governed mainly by fractionating plagioclase in the magmas of the frontal zone while they are controlled mainly by clinopyroxene and probably hornblede and biotite in the inland zone. The phenocryst assemblage of the lavas does not conflict with this model.

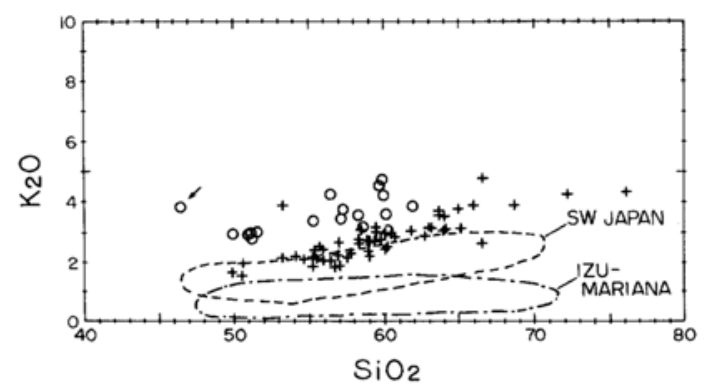

Fig. 4. $\mathrm{SiO}_{2}-\mathrm{K}_{2} \mathrm{O}$ variation diagram of the volcanic rocks in southern Peru. +: rocks in the frontal zone, $o$ : rocks in the inland zone. Arrow indicates olivine-augite basanite (AC-01). The general range of the rocks of the southwest Japan are and Izu-Mariana arc is also shown. 


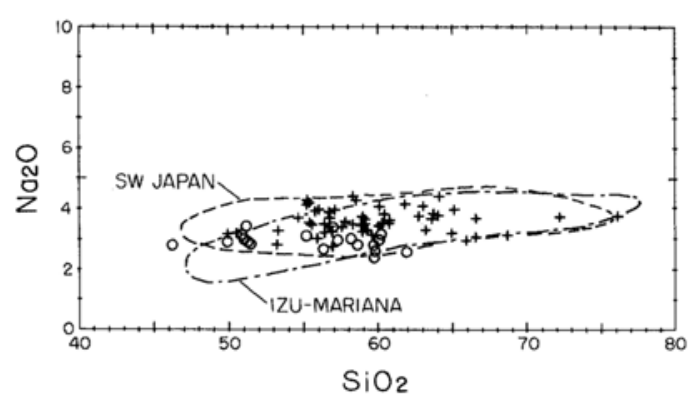

Fig. 5. $\mathrm{SiO}_{2}-\mathrm{Na}_{2} \mathrm{O}$ variation diagram of the volcanic rocks in southern Peru. Symbols are the same as in Fig. 4.

\section{Geographic MapPING of Contents of CERTAin Elements}

Coherent geographic changes in contents of certain elements in volcanic rocks as the products of arc volcanism across the arc are well established. For example ARAMAKI and UI (1982, 1983) demonstrated that the $\mathrm{SiO}_{2}-$ normalized $\mathrm{K}_{2} \mathrm{O}$ contents of the Japanese Quaternary volcanic rocks show a very regular

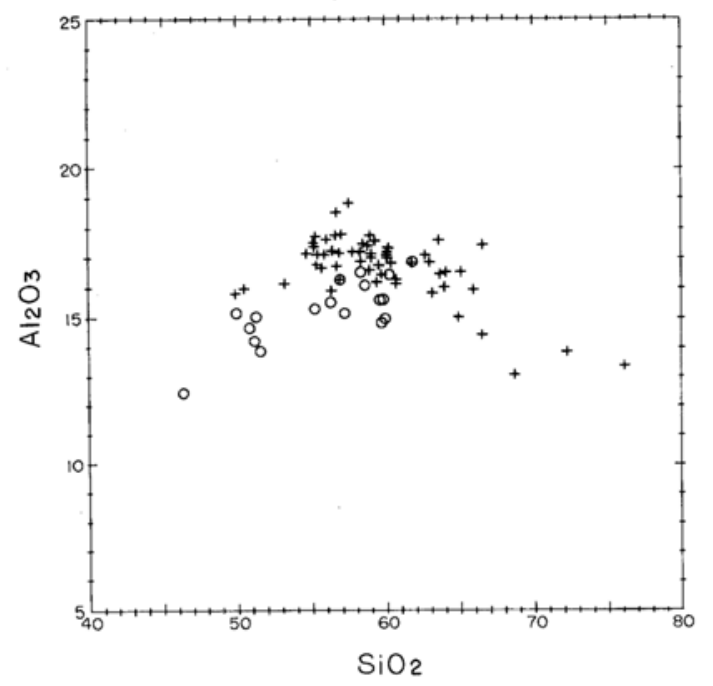

Fig. 6. $\mathrm{SiO}_{2}-\mathrm{Al}_{2} \mathrm{O}_{3}$ variation diagram of the volcanic rocks in southern Peru. Symbols are the same as in Fig. 4.

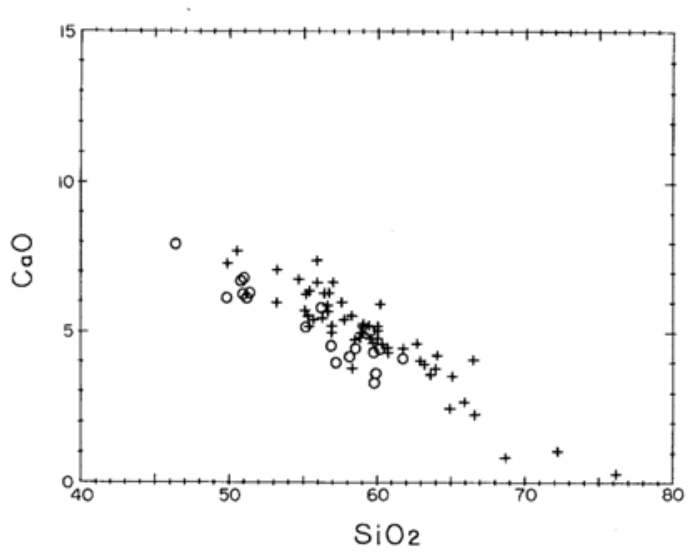

Fig. 7. $\mathrm{SiO}_{2}-\mathrm{CaO}$ variation diagram of the volcanic rocks in southern Peru. Symbols are the same as in Fig. 4.

variation across the most part of the volcanic front with certain undulatory changes along the arc. Especially it was noted that behind the junction of two arcs, the regularity appears to be broken by unusually low $\mathrm{K}_{2} \mathrm{O}$ contents of the lavas (ARAMAKI and UI, 1983).

Figure 8 shows the geographical variation of the $\mathrm{K}_{2} \mathrm{O}$ contents. The $\mathrm{K}_{2} \mathrm{O}$ values are normalized against $\mathrm{SiO}_{2}=60 \%$ on the assumption that the $\mathrm{SiO}_{2}-\mathrm{K}_{2} \mathrm{O}$ variation follows a standard trend which is a set of straight lines obtained from more than 100 variation diagrams of the Japanese Quaternary volcanoes. All these standard trend lines are subparallel to each other but their slope increases with the $\mathrm{K}_{2} \mathrm{O}$ content. They are expressed as follows (ARAMAKI and UI, 1983):

$$
\begin{gathered}
\mathrm{Z} \times\left(0.365 \times \mathrm{SiO}_{2}(\mathrm{wt} \%)-1.0\right) \\
-3.65 \times \mathrm{K}_{2} \mathrm{O}(\mathrm{wt} \%)=2.46
\end{gathered}
$$

where $\mathrm{Z}$ is a constant for any particular "standard trend line". Using this equation, parameters indicating the level of $\mathrm{K}_{2} \mathrm{O}$ content such as the k-values of Dickinson (1975) can be computed from any single chemical analysis. In the following, the $\mathrm{K}_{2} \mathrm{O}$ content standardized to $\mathrm{SiO}_{2}=60 \%$ is designated as $\mathrm{K}_{2} \mathrm{O}\left(\mathrm{SiO}_{2}=60\right)$. 


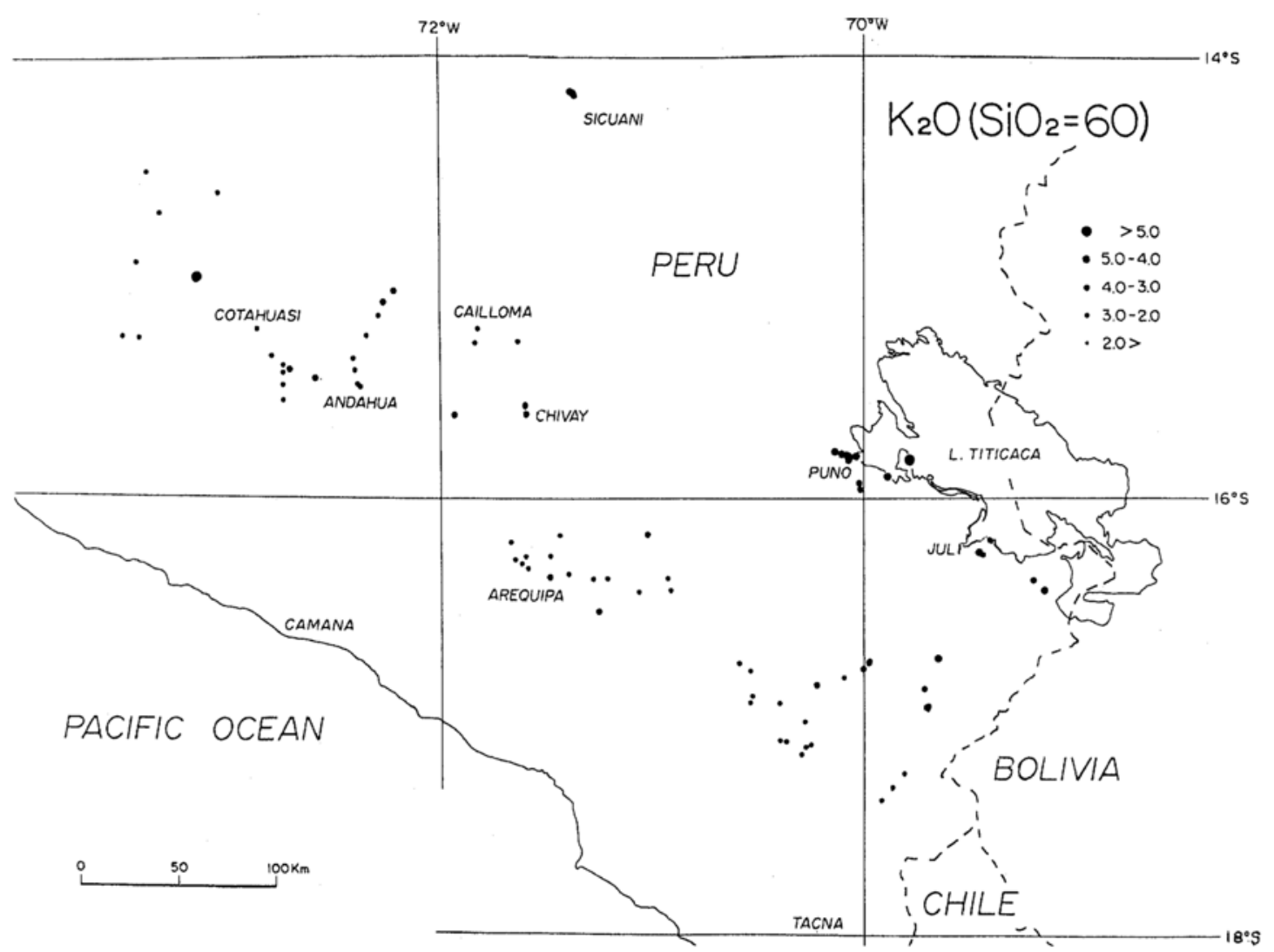

Fig. 8. Map showing the geographic variation of $\mathrm{K}_{2} \mathrm{O}\left(\mathrm{SiO}_{2}=60\right)\left(\mathrm{K}_{2} \mathrm{O}\right.$ content normalized to $\left.\mathrm{SiO}_{2}=60 \%\right)$ of the volcanic rocks in southern Peru.

\section{Spatial Trends of $\mathrm{K}, \mathrm{Na}, \mathrm{Sr}$ And $\mathrm{Ba}$ Contents in Southern Peru}

In Fig. 8 , it is clearly shown that $\mathrm{K}_{2} \mathrm{O}$ $\left(\mathrm{SiO}_{2}=60\right)$ values systematically increase away from the volcanic front (or trench axis). This regularity is pointed out by previous workers like LeFÈvre $(1973,1979)$. The general trend is the most regular of all the elements examined and the only exception is the unusually K-rich augite andesite (PPD-101) to the northwest of Cotahuasi. When compared with the depth of the Benioff zone beneath this region (HASEGAWA and SACKS, 1981), $\mathrm{K}_{2} \mathrm{O}\left(\mathrm{SiO}_{2}=60\right)$ increases about $1.5 \%$ in average with $100 \mathrm{~km}$ increase in the depth of the Benioff zone away from the front. As discussed by ArAmaKI and Ui (1983), this rate is much lower than in the transect across the northern Honshu arc of Japan (2.5 to
$3.0 \%$ per $100 \mathrm{~km})$. Since our samples covered quite a large range of geologic age (6 Ma to present, KANEOKA and GUEVARA, 1984) as LEFÈVRE's samples did, direct comparison with the Japanese case $(<1 \mathrm{Ma}$ to present) may not be well justified.

Figure 9 shows distribution of $\mathrm{Na}_{2} \mathrm{O}$ contents of samples. As the $\mathrm{Na}_{2} \mathrm{O}$ content does not increase appreciably with the $\mathrm{SiO}_{2}$ content (Fig. 5), $\mathrm{Na}_{2} \mathrm{O}$ contents are directly plotted. As shown in Fig. 9, $\mathrm{Na}_{2} \mathrm{O}$ content is generally lower in the inland zone than in the frontal zone. In may other arcs, including arcs of the Japanese islands (ARAMAKI and $\mathrm{UI}, 1983$ ), $\mathrm{Na}_{2} \mathrm{O}$ content does not show any regular zonal variation across the arc. In our present study, the apparent "reverse" zonation of $\mathrm{Na}_{2} \mathrm{O}$ is quite striking and can not be explained by such fractional crystallization processes as those discussed by ONUMA 


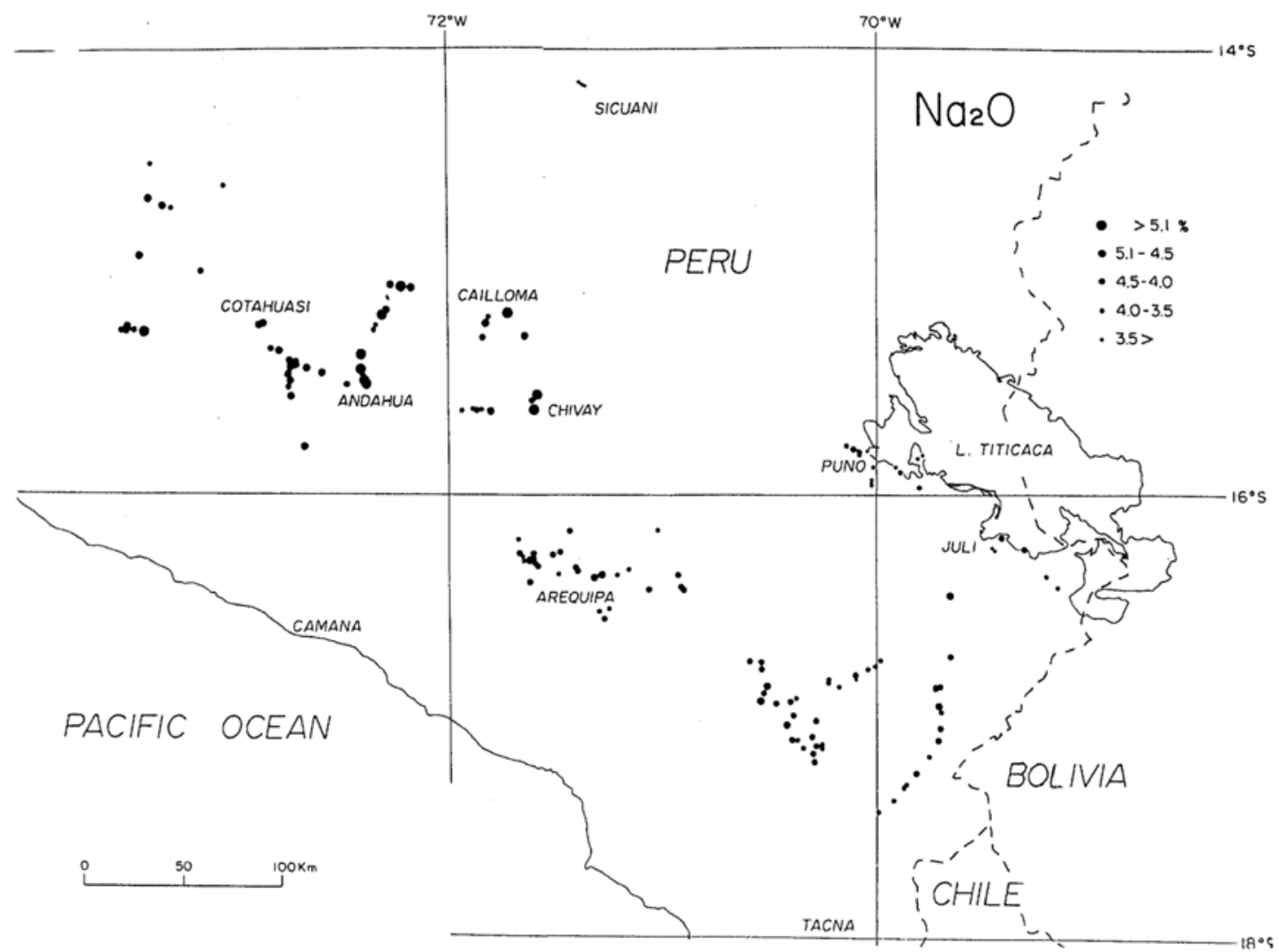

Fig. 9. Map showing the geographic variation of $\mathrm{Na}_{2} \mathrm{O}$ contents in the volcanic rocks in southern Peru.

and Montoya (1984). Also interesting is the difference of $\mathrm{Na}_{2} \mathrm{O}$ levels in southeastern (AR-, $\mathrm{CH}-$, OM-, and MA- groups; see Appendix 1) and northwestern (CH-, CV-, CM-, OP-, PA- and PPD- groups) sectors. The $\mathrm{Na}_{2} \mathrm{O}$ content is the highest in the northwestern sector of the frontal zone, intermediate in southeastern sector of the frontal zone and the lowest in the inland zone. Therefore, the $\mathrm{Na}_{2} \mathrm{O}$ content apparently shows variations across and along the arc. In this case again it is difficult to assign any particular mineral phase(s) responsible for this difference through fractional crystallization.

Regional variations of the $\mathrm{Sr}$ and $\mathrm{Ba}$ contents are shown in Figs. 10 and 11, respectively. The data are from Onuma and Montoya (1984). The $\mathrm{Sr}$ content regularly decreases with the $\mathrm{SiO}_{2}$ content but the $\mathrm{Ba}$ content stays more or less constant. However, direct plot on the map clearly shows geographical changes both in $\mathrm{Sr}$ and $\mathrm{Ba}$ contents. Both increase away from the volcanic front in the same manner as the $\mathrm{K}$ content. In the northwestern sector of the frontal zone, the level of $\mathrm{Sr}$ is intermediate and very similar to the relative level of $\mathrm{K}$, but $\mathrm{Ba}$ appears to show higher level there.

In summary, $\mathrm{K}, \mathrm{Sr}$ and $\mathrm{Ba}$ contents all show regular increase away from the front as well as a slight northwestward increase along the arc while the $\mathrm{Na}$ content decreases away from the front and is conspicuously higher in the northwestern frontal zone.

Acknowledgements-This work was done under a project entitled "Geochemical investigation of the Central Andes volcanic zone, southern Peru" under the auspices of the Overseas Scientific Research, Ministry of Education, Science and Culture (Grant Nos. 504112 and 56043012). 


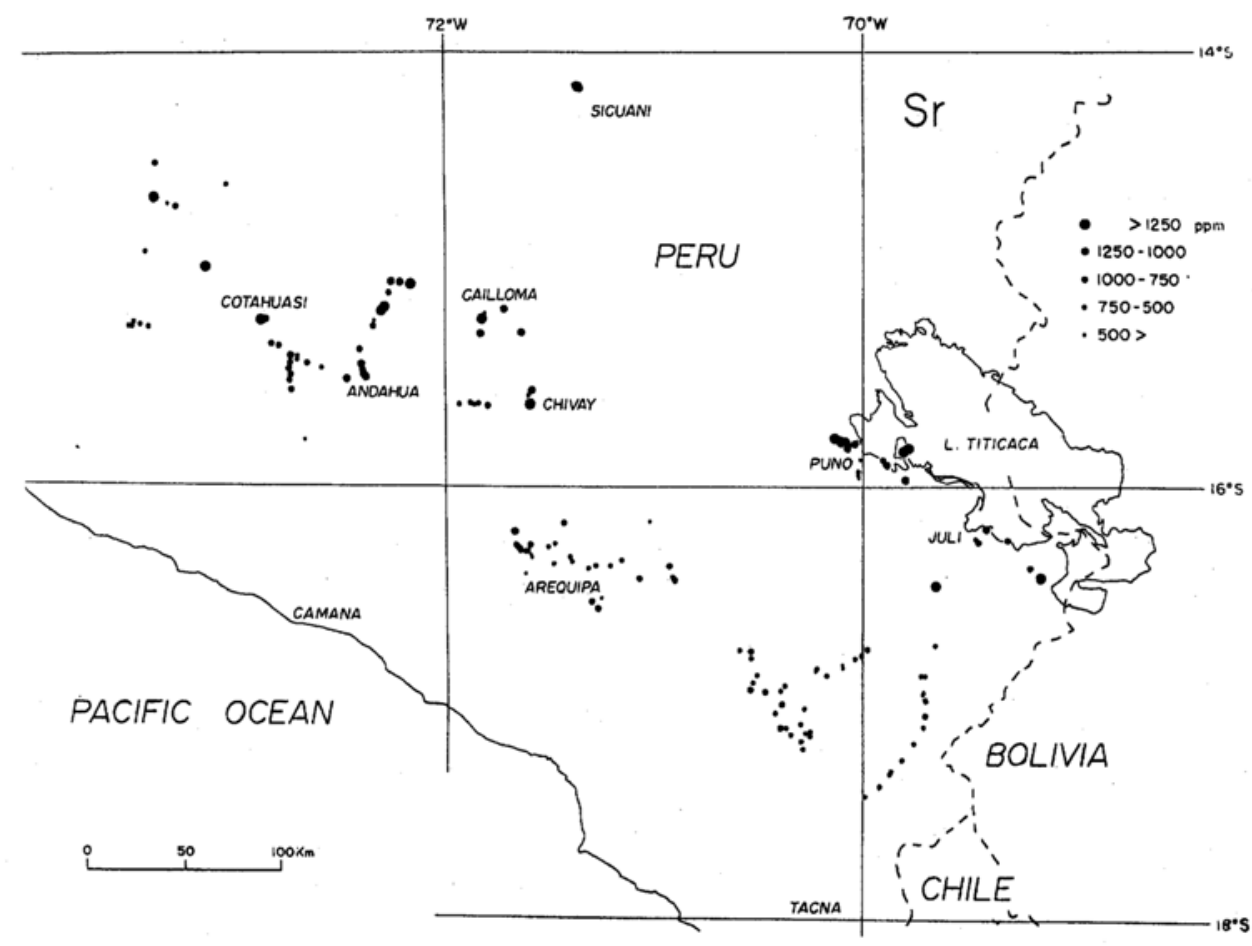

Fig. 10. Map showing the geographic variation of Sr contents of the volcanic rocks in southern Peru.

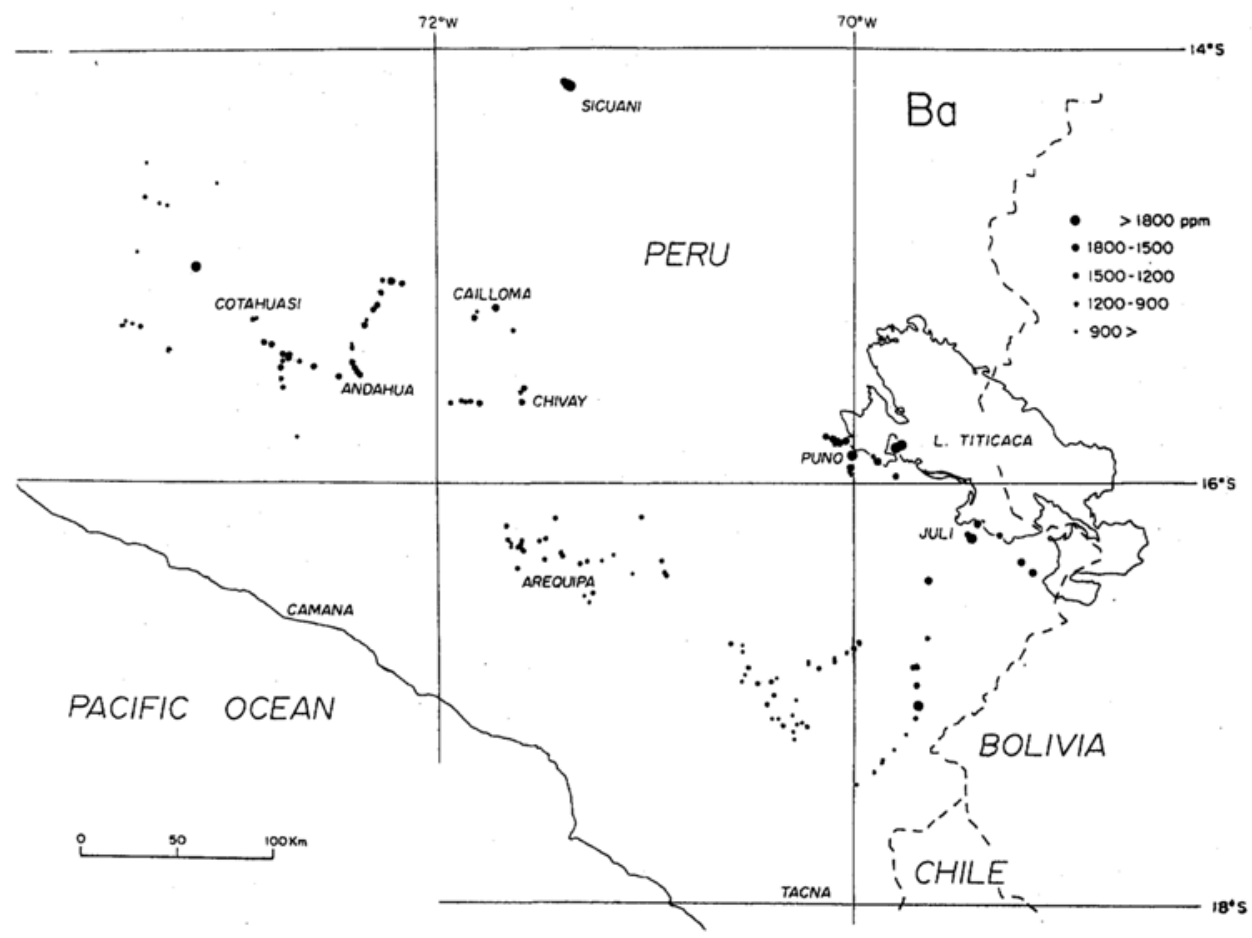

Fig. 11. Map showing the geographic variation of Ba contents of the volcanic rocks in southern Peru. 


\section{REFERENCES}

ARAMAKI, S. and UI, T. (1978) Major element frequency distribution of the Japanese Quaternary volcanic rocks. Bull. Volcanol. 41, 390-407.

ARAMAKI, S. and UI, T. (1982) Japan. In Andesites: Orogenic andesites and related rocks (ed. R. S. THORPE), 259-292. Wiley, Chichester.

ARAMAKI, S. and UI, T. (1983) Alkali mapping of the Japanese Quaternary volcanic rocks. J. Volcanol. Geotherm. Res. 18, 549-560.

CUMmings, D. and SCHILleR, G. I. (1971) Isopach map of the earth's crust. Earth Sci. Rev. 7, 97-125.

Dickinson, W. R. (1975) Potash-depth (K-h) relations in continental margin and intraoceanic magmatic arcs. Geology 3, 53-56.

HaSegawa, A. and SACKS, I. S. (1981) Subduction of the Nazca plate beneath Peru as determined from seismic observations. J. Geophys. Res., Sect. 86, 4971-4980.

KANEOKA, I. and GuevarA, C. (1984) K-Ar age determination of upper Tertiary and Quaternary Andean volcanic rocks, southern Peru. Geochem. J. 18, 233-239.

LEFÈVRE, C. (1973) Les caractères magmatiques du volcanisme plio-quaternaire des. Andes dans le Sud de Pérou. Contrib. Mineral. Petrol. 41, 259-272.

LEFÈVRE, C. (1979) Un exemple de volcanisme de marge active dans les Andes du Pérou (sud) du miocène à l'acruel. Thesis, D. Sc., 555 p. (MS).

MATSUMoto, R. and URABE, T. (1980) An automatic analysis of major elements in silicate rocks with X-ray fluorescence spectrometer using fused disc samples. Gansęi Kobutsu Kosho Gakkaishi 75, 272-278 (in Japanese).

ONUmA, N. and MonTOYA, M. (1984) Sr/Ca-Ba/Ca systematics of volcanic rocks from the Central Andes, Southern Peru and its implication for Andean magmatism. Geochem. J., 18, 251-262.

\section{APPENDIX 1}

\section{LIST OF SAMPLES}

\section{Abbreviations}

ol olivine aug autite hyp hypersthene

hb hornblende biot biotite plag plagioclase

$<$ Numbers at extreme left refer to those in Appendix 2>

1 TU-01 Hb-biot andesite, Maso Pillone, Characato Quad.

CH-01 Hyp-hb andesite, Barroso Group. $8 \mathrm{kmE}$ of Chiuata.

2 CH-02 Aug-hb-hyp andesite, $13 \mathrm{~km}$ ENE of Chi- huata, on Arequipa-Juliaca highway.

3 CH-03 Hb-aug-hyp andesite, W of Laguna Salinas, at $4,300 \mathrm{~m}$.

4 CH-04 Biot-aug-hb andesite, NW of Cerro Baldio, SE of Laguna Salinas.

5 CH-05 Hb-aug-hyp andesite, $\mathrm{S}$ foot of Volcan Ubinas.

CH-06 Hyp-aug-hb andesite, SE foot of Volcan Ubinas. $1.8 \mathrm{~km}$ ESE of road junction.

6 CH-07 Hb-hyp andesite, W foot of Volcan Ubinas, at $4,570 \mathrm{~m}$.

CH-08 Hyp andesite, probably of Llallahui Group. Road cut $0.7 \mathrm{~km} \mathrm{SSW}$ of Huito, on Laguna Salinas.

7 AR-01-01 Aug-biot-hb andesite, upper layer, Cerro Atalaya, E of Arequipa..

AR-01-02 Aug-hyp andesite. Same locality as above.

8 OP-13 Aphyric andesite, $1.3 \mathrm{~km} \mathrm{ENE} \mathrm{of} \mathrm{Anda-}$ hua.

AR-02-01 Aug-hb-biot andesite, Lava from Volcan Chachani. Cerro Cortaderas, NE of Arequipa.

9 AR-02-02 Aug-hyp-hb-biot andesite, Lava from Volcan Chachani. Same locality as above.

10 AR-03 Plag andesite, Quebrada los Andes, $16 \mathrm{~km}$ ENE of Arequipa.

AR-04 Aug-hyp-hb andesite, lava flow from Chachani. "Quebrada los Andes", $c a$. $16 \mathrm{~km}$ from Arequipa.

11 AR-05 Aug-hyp andesite, El Barretado, $20 \mathrm{~km} \mathrm{E}$ of Arequipa.

AR-06 Aug-hb-hyp andesite, lava from Chachani. "Quebrada el Cuico" on highway Arequipa-Yura, $23 \mathrm{~km}$ from Arequipa.

AR-07-01 Aug-hyp-hb andesite, lava flow from Chachani. "Uyupampa" near railroad Arequipa-Puno, $5 \mathrm{~km} \mathrm{~N}$ of Yura.

12 AR-07-02 01-hb (? opacite) andesite, Lava flow from Chachani. Entrance of "Uyupampa", 5 $\mathrm{km} \mathrm{N}$ of Yura.

AR-08 Hb-hyp andesite, lava flow from Chachani. "Quebrada Cabreira" $16 \mathrm{~km} \mathrm{~N}$ of Arequipa.

13 AR-09 Hyp-hb andesite, Near Tampo de Pisag, $22 \mathrm{~km} \mathrm{~N}$ of Arequipa.

14 AR-10 Hyp-hb andesite, Pampa Kutypamapa, 34 km NNE of Arequipa.

AR-11 HB (opacite)-aug-hyp andesite, lava from Volcan Pichupichu. "Cerro Yanaorco" on highway Arequipa-Omate, $50 \mathrm{~km}$ ESE from Arequipa.

15 AR-12 Ol-aug-hb-hyp andesite, Lava flow from Pichuchu. Cerro Timpore.

AR-13 Ol-aug andesite, Lava from Pichupichu. 
"Cerro Aqua Buena," $45 \mathrm{~km}$ ESE of Arequipa.

AR-14 Welded rhyolitic tuff (eutaxitic), quarry of sillar. $4 \mathrm{~km} \mathrm{NW}$ of Arequipa airport.

16 AR-15 Plag rhyolite, reddish pumice. $4.5 \mathrm{~km} \mathrm{NW}$ of Arequipa airport.

AR-16 Biot rhyolite, welded tuff, a sillar. Near Cantera del Huyaco" $100 \mathrm{~km}$ W of center of Arequpa.

17 AR-17-01 Aug-hb-hyp andesite, S flank of El Misti. AR-17-02 Hyp-hb andesite, lava flow. Same locality as above.

18 CV-01 Biot-aug-hyp andesite, younger lava flow from Nevado Hualka Hualka. ChivayHuambo highway.

CV-02 Biot-aug-hyp andesite, same as above. $0.5 \mathrm{~km} \mathrm{~W}$ of Chirinuevo, on highway Chivai-Huambo.

CV-03 Biot-aug-hyp andesite, similar to CV-02. S of Pujro.

CV-04 Biot andesite (carbonate alteration), a block in lahar dep. from Hualkahualka. At Pinchollo.

CV-05 Hyp-biot andesite, older lava flow of Nevado Hualkahualka. Quarry S of Madrigal, on highway Chivay-Huambo.

19 CV-06 Hb(?)-biot(?)-aug andesite, Barroso Group. $4 \mathrm{~km}$ NNW of Chivay.

CV-07-01 Aphyric andesite, dark. N of Chivay.

20 CV-07-02 Aphyric andesite, gray. N of Chivay.

CV-08 Opacite andesite, glassy. At Ccayachape, $7 \mathrm{~km} \mathrm{~N}$ of Chivay.

21 CM-01 Aphyric andesite, SE part of Cailloma Caldera. W of Cerro Pillunes.

CM-02 Aug-opacite andesite, lava flow from Cerro Cosana, at the center of Cailloma Caldera. $0.3 \mathrm{~km} \mathrm{~W}$ of Muyurina.

CM-03 Densely-welded tuff, underlying flat lava flow of Barroso Group. $0.4 \mathrm{~km} \mathrm{SW}$ of San Antonio, $5 \mathrm{~km} \mathrm{SW}$ of Cailloma.

22 CM-04 Aug andesite, NW oart of Cailloma Caldera. $7 \mathrm{~km} \mathrm{~W}$ of Cailloma.

23 CM-05-01 Ol andesite. N flank of Cerro Antaymarca, a scoria cone. $14 \mathrm{~km} \mathrm{SSW}$ of Cailloma.

OP-01 Aphyric andesite, pseudobrookite, hb, biot, K-feldspar in druse. Lava flow from Cerro Cajchaya. NE of Laguna Corecocha.

24 OP-02 Aphyric andesite, lava flow from Cerro Cajchaya.

OP-03 Aphyric andesite, columnar lava of Barroso Group. N edge of Cerro Marcani, $2.8 \mathrm{~km} \mathrm{SE}$ of Pueblo Arcata.

25 OP-04 Aug-hyp andesite, Barroso Group. Lava flow from Cerro Antapuna.

26 OP-05 Aphyric andesite, lava flow from Cerro Antapuna. $5 \mathrm{~km}$ Se of Cerro Antapuna.

OP-06 Aphyric andesite, lava from Cerro Antapuna. $1.8 \mathrm{~km}$ SSW of OP-05.

OP-07 Aphyric andesite, possibly Tacaza Group. $1 \mathrm{~km} \mathrm{NE}$ of Orcopampa, on the road.

27 OP-08 Aphyric dacite, ?boulder. SW part of Orcopampa.

OP-09 Andesite boulder on river bed of Rio Andahua, SE of Cerro Paiche Loma.

OP-10-01 $\mathrm{Hb}($ ?)-biot(?) andesite, thick $(>100 \mathrm{~m})$ flow. E bank of Rio Andahua, $13 \mathrm{~km}$ NNW of Andahua.

$28 \mathrm{OP}-10-02 \mathrm{Hb}($ ?)-aug andesite. Same locality as above.

OP-11-01 Aphyric andesite, probably lava from Cerro Ticsho. 1.2 km SE of Latoma, $4 \mathrm{~km} \mathrm{NW}$ of Andahua.

OP-11-02 Aphyric andesite, dark gray, slightly altered. Same as above.

OP-12 Opacite andesite, a thick lava flow of Barroso Group. $1 \mathrm{~km} \mathrm{SW}$ of Cerro Ticsho.

OP-13 Aphyric andesite, margin of lava flow 10 m thick. $1.3 \mathrm{~km}$ WNW of Andahua.

OP-14-01 Aphyric andesite. $0.8 \mathrm{~km} \mathrm{~W}$ of center of Andahua.

29 OP-14-02 Ol-aug andesite. Center of Andauha.

OP-15-01 Andesite, Barroso Group (?). $2.3 \mathrm{~km}$ NNW of Cerro Pucaylla on AndahuaArma highway.

30 CS-01-01 $\mathrm{Hb}($ ?)-aug-hyp andesite, lava flow probably from Nevado Coropuna. N flank of Cerro Fiahuamani.

CS-01-02 Hb-aug-hyp andeiste. Same as above. CS-01-03 Hb-aug-hyp andesite. Same as above.

CS-02 Opacite-aug-hyp andesite, lava flow from Nevado Coropuna. $7.5 \mathrm{~km}$ ENE of Arma.

31 CS-03-01 Hb-aug-hyp andesite, lava flow from Cerro Ccorecahuana. $\mathrm{N}$ foot of Cerro Ocoruro.

CS-03-02 Plag andesite, lava from Cerro Ccorecahuana. $1.7 \mathrm{~km}$ ENE of Arma.

CS-04 Aug-hyp-hb andesite, lava probably from Cerro Antapuna. $1.7 \mathrm{~km}$ ENE of Arma.

32 CS-05 Aphyric anciesite, lava of Barroso Group. $4.5 \mathrm{~km}$ SE of Cotahuasi.

CS-06 Aug-hyp andesite, same lava flow as above. $4 \mathrm{~km}$ SSE of Cotahuasi.

CS-07-01 Hyp-hb andesite, in morane from Nevado Solimana. $2.1 \mathrm{~km} \mathrm{~W}$ of Huaytapampa and $1.5 \mathrm{~km} \mathrm{SE}$ of Visca Grande.

33 CS-08 Plag andesite, lava flow from Nevado Solimana. $1.7 \mathrm{~km} \mathrm{SE}$ of Huaytapampa. 
34 CS-09 Aphyric andesite. $1.4 \mathrm{~km} \mathrm{NW}$ of Arma, on Rio Arma.

35 CS-10-01 Aug-hb-hyp andesite, older flow from Nevado Coropuna. $4 \mathrm{~km} \mathrm{~S}$ of Arma.

CS-10-02 Hyp-hb-aug andesite. Same as above.

CS-11 Aug-hyp-hb andesite, lava dome of Cerro Kencho. $7 \mathrm{~km} \mathrm{SSW}$ of Arma.

CS-12-01 Hb-biot-hyp andesite, very young lava flow from Nevado Coropuna. NW of Cerro Sepulturayoc, $1.5 \mathrm{~km} \mathrm{~N}$ of Campamento Sique.

CS-12-02 Same as above.

$36 \mathrm{CS}-12-03 \mathrm{Hb}$-aug andesite. Same as above.

37 CS-14 Aug-hyp andesite. S of Cerro Reyusja and $2 \mathrm{~km} \mathrm{NW}$ of Laguna Pallacocha.

CS-15 Hyp-hb-biot dacite, welded tuff of Senca Group. West of Santa Rosa, $6 \mathrm{~km}$ NNW of Chuquibamba.

PA-01 Hb-hyp andesite, lava from Nevado Sara Sara. $1 \mathrm{~km} \mathrm{~W}$ of Huallhua.

38 PA-02 $\mathrm{Hb}($ ?)-aug-hyp andesite, Sara Sara Group (?). NE flank of Nevado Sara Sara. $1 \mathrm{~km}$ W of Huallhua.

PA-03 Biot-hb-hyp andesite, lava from Nevado Sara Sara. $1 \mathrm{~km}$ E of Quilcata, on IncuyoPausa road.

PA-04 Aug-hyp andesite, lava from Cerro Asccase. $4 \mathrm{~km} \mathrm{NW}$ of Quilcata.

39 PA-05 Aug-hyp andesite, Barroso Group. $2 \mathrm{~km}$ $S$ of Huaculla.

PA-06 Hb-hyp-biot-aug andesite. $1 \mathrm{~km} \mathrm{~W}$ of PA05.

40 CZ-01 Aug-hyp "shoshonite", relatively young block lava. Plagand quartz xenocrysts and abundant xenoliths. $2 \mathrm{~km} \mathrm{~W}$ of San Pedro, near Siquani.

41 CZ-02-01 Hyp(?)-ol-aug "shoshonite," rich in granitic xenoliths up to $30 \mathrm{~cm}$ across. $0.2 \mathrm{~km} \mathrm{~W}$ of Anansaya, W of San Pedro.

CZ-02-02 Same as above.

42 CZ-03 Aug-hyp "shoshonite", rich in xenoliths. Quellcocunca, $2 \mathrm{~km}$ SE of Tinta.

43 CZ-04 Aphyric andesite, valley-filling flow: On Puno-Cuzco highway between Andahuay. lillas and Oropesa.

44 PU-01 Aug-hyp-hb "shoshonite". N foot of Cerro Atojllane, $5.5 \mathrm{~km}$ NW of Puno.

PU-02-01 Oxyhornblende "shoshonite". S flank of Cerro Coronado, $6 \mathrm{~km} \mathrm{NW}$ of Puno.

45 PU-02-02 Ol-aug-hb "shoshonite". Same as above.

46 PU-03 Ol-aug "shoshonite". S flank of Cerro Pilchane, $11 \mathrm{~km}$ NW of Puno.

47 PU-04 $\mathrm{Hb}($ ?)-ol-hyp "shoshonite", lava flow from Cerro Coronado. $8 \mathrm{~km} \mathrm{NW}$ of Puno.
48 PU-05 Aug-ol "shoshonite", lava flow of Cerro Chupi. $4.5 \mathrm{~km} \mathrm{~W}$ of Puno.

49 PU-06 Ol-aug "shoshonite", lava flow from Cerro Azoquine. $2 \mathrm{~km} \mathrm{~N}$ of Puno.

50 PU-07 Aug-biot-hb-hyp andesite, E flank of Cerro Ticani. $10 \mathrm{~km} \mathrm{~S}$ of Puno.

PU-08 Biot-hb-aug-hb andesite, lava flow from Cerro Cactiri. On Puno-Moquegua highway.

51 PU-09 Aug-hyp-hb-biot andesite, Barroso Group, altered. Lava flow from Cerro Cactiri(?). $3 \mathrm{~km} \mathrm{SE}$ of Quimsachata.

52 AC-01 Aug-ol basanite, lava flow from unnamed Cerro. Cerro Chiana on Lago Titicaca, $15 \mathrm{~km} \mathrm{~N}$ of Acora.

AC-02 Aug-ol basanite, lava flow from Cerro Paco. $1 \mathrm{~km} \mathrm{~S}$ of AC-01.

AC-03 Ol-aug basanite. $2 \mathrm{~km} \mathrm{NW}$ of Chuchito, on Puno-Ilave highway.

53 AC-04 Aug-hyp andesite, partly altered. $0.5 \mathrm{~km}$ $\mathrm{S}$ of Chuchito.

JL-01-01 Biot rhyolite, lava flow of Cerro Pucara. On S flank of Cerro Oucara, $4 \mathrm{~km} \mathrm{SW}$ of Juli.

54 JL-01-02 Aug-hyp andesite, boulder on bank of Rio Salado. Same as above.

JL-01-03 Aug-hyp andesite. Same as above.

JL-01-04 Biot rhyolite, lava flow similar to JL-0101.

55 JL-02 Aug-hyp-hb andesite, Barroso Group. Between Cerro Pucara and Cerro Caballune.

JL-03 Ol-aug andesite, probably from Cerro Tutacane. $5 \mathrm{~km}$ NE of Juli.

JL-04 Hb-biot dacite, lava flow from Cerro Tokokcahua. $\quad 2.5 \mathrm{~km} \mathrm{NW}$ of Pomate.

57 JL-10 Biot-hb-aug-hyp andesite, lava flow from Cerro Pueara. $14 \mathrm{~km}$ SE of Pomate.

$58 \mathrm{JL}-11$ Altered pyroxene andesite. $25 \mathrm{~km} \mathrm{SE}$ of Pomate.

59 TA-01 Aug-hb andesite, lava from Nevado Chuquiananta. Quebrrada Ichupampa.

TA-02 Hb-biot dacite, lava from Nevado Chuquiananta. $1 \mathrm{~km} \mathrm{~W}$ of Tacalaya-Laguna Suches.

TA-03 Aug-biot-hb andesite, lava flow from Volcan Tutupaca. NW flank of V. Tutupaca, on Tacalaya-Laquna Suches road.

60 TA-04 Hb-aug-hyp andesite, lava flow of Rio Tacalaya. Quilcata on the carretera Tacalaya-Laguna Suches.

TA-05-01 Aug-biot-hyp andesite, lava flow from Pampa Turun Turun. Huayllani, on Quilieata-Huayllani road.

TA-05-02 Aug-biot-hyp andesite, lava flow over- 
lying TA-05-02.

TA-06 Biot-hb-aug-hyp andesite, lava flow from Cerro Estrone. Cerro Pagrilaca on triple junction Candarave-Huanuara-Cairani.

61 TA-07 Hb-aug-hyp andesite, lava flow of Cerro Totorani. $1 \mathrm{~km} \mathrm{NW}$ of Cerro Totorani.

62 TA-08 Biot-hb dacite, lava flow from Cerro Calientes. On the carretera ArananeNina Yucamane.

TA-09 Hb-biot andesite, lava flow from Cerro Calientes.

63 TA-10 Hb-aug-hyp andesite, lava flow from Cerro Nazaparco. $1 \mathrm{~km} \mathrm{E}$ of Aranane.

TA-11 Aug-hyp-hb andesite, lava flow from Volcan Tutupaca. Quebrada Huayjaque, $0.2 \mathrm{~km} \mathrm{~W}$ from Candarave-Laguna Suches road.

64 TA-12 Hb-biot-aug-hyp andesite, lava flow of Tutupaca. Quebrada Zuripujo.

65 OM-01 Aug-hyp-hb andesite, lava flow of Cerro Laramcalane. $\mathrm{N}$ flank of Cerro Laeramcalane, along the road from Cuajone to Mazo Cruz.

$66 \mathrm{OM}-02 \mathrm{Hb}$ andesite, lava flow of Cerro Camillata. Along the road from Cuajone to Carumas.

67 OM-03 Biot-hb dacite, possibly older lava of Volcan Tiscani.

OM-04-01 Biot-hb (opacitized) dacite, on SE flank of Cerro Toro Bravo. $1 \mathrm{~km} \mathrm{SE}$ of Laguna Toro Bravo.

OM-04-02 Same as above.

68 OM-05 Aug-hb andesite, lava flow from Cerro Chinilaca. $\mathbf{N}$ of Pampa de Huamajalso.

OM-06 Aug-hyp andesite, lava from Volcanico Chila. $4 \mathrm{~km} \mathrm{~W}$ of summit of Cerro Jumajalso.

OM-07 Aug-biot-hb andesite, lava flow from Nevado Arundane. At Ojos de Agua in the Pampa Titijones.

69 OM-08 Biot-aug-hyp andesite, lava flow of Cerro Carinani. S side of Laguna Suches.

OM-09 Aug-hyp-hb andesite, lava flow probably from Cerro Baajnani. On Laguna Suches, $2 \mathrm{~km}$ NE of Suches.

70 OM-10 Aug-hyp andesite, Volcanica Chila (?), E flank of Cerro Yuncane. $1 \mathrm{~km} \mathrm{~N}$ of Condori.

OM-11 Aug-hb andesite, lava flow from Cerro Pacchiangui. $1 \mathrm{~km} \mathrm{E}$ of Challamoco.

OM-12 Biot-hb-hyp-aug andesite, lava flow of Cerro Vizcachas. $5 \mathrm{~km} \mathrm{E}$ of Laguna Viscacha o Canocota.

OM-13 Aug-hyp andesite, lava flow from Cerro Ichipata. At Achacpujo, on CuajoneMaso Cruz highway.
OM-14 Plag rhyolite, lava flow of Cerro Quesllampo. Apaceta Organune, on the carretera of Candarave-Mazo Cruz.

OM-15 Aug-hyp andesite, lava from Cerro Chiapujo. On Cuajone-Mazo Cruz road.

72 OM-16 Aug-hyp-hb andesite, lava flow from Cerro Anconaza. On the carretera of Candarave-Mazo Cruz.

73 MC-01 Biot(?)-hb andesite, Barroso Group. $3 \mathrm{~km}$ NW of Sallacruza.

MC-02 Biot-hb-hyp-aug andesite, lava flow from Cerro Huenque. $6 \mathrm{~km} \mathrm{E}$ of Mazo Cruz.

74 MC-03 Aug-hb-hyp andesite, lava flow overlying the Capillune Formation. $\mathbf{N}$ flank of Cerro San Francisco de Pachapaque.

MC-04 Hb-hyp andesite, Barroso Group (?). On W flank of Cerro Taruja, $15 \mathrm{~km} \mathrm{~S}$ of Mazo Cruz.

75 MC-05 $\mathrm{Hb}$ andesite, probably Barroso Group. E flank of a hill along Rio Llusta, $15 \mathrm{~km}$ S of Mazo Cruz.

76 MC-06 Aug(?)-hb(?) dacite, lava flow of Cerro Acsatata Grande. $28 \mathrm{~km} \mathrm{~S}$ of Mazo Cruz.

MC-07-01 Aug-hyp andesite, on E flank of Cerro Huallpanasa, $0.1 \mathrm{~km} \mathrm{E}$ of Rio Humalso.

MC-07-02 Biot-aug-hyp andesite. Same as above.

MC-08 Biot-aug andesite, Barroso Group. E flank of Cerro Murmuntane. On Mazo Cruz-Tarata highway.

MC-09 Biot-hb-hyp andesite, lava flow of Cerro Huancure. On NW flank of Cerro Huancure, on Mazo Cruz-Tarata road.

MC-10 Aug-hyp andesite, lava flow of Cerro Capaca. $2 \mathrm{~km} \mathrm{SW}$ of Chila.

77 MC-11 Aug-hyp andesite, boulder of Cerro Tifiri over the Pleistocene moraines. Along the road between Mazo Cruz and Tarata.

MC-12 Green biot-hb dacite, lava flow of Cerro Antajave. Near Cerro Azufre, $76 \mathrm{~km} \mathrm{~S}$ of Mazo Cruz.

78 MC-13 Biot-hb dacite, boulder probably from Cerro Purupuruni. Along the road between Mazo Cruz and Tarata.

79 MC-14 $\mathrm{Hb}$ andesite, lava flow of Cerro Quequesani. Along the road between Mazo Cruz and Tarata:

MC-15 Hb-aug-ol-hyp andesite, lava flow of Cerro Putina. On Mazo Cruz-Tacna highway, $10 \mathrm{~km} \mathrm{NE}$ of Tarata.

80 PPD-10 Hb(?)-aug andesite, Barroso Group. S flank of Cerro Yanasaya.

81 PPD-30 Ol basalt, Barroso Group. E flank of Cerro Chucchurani, very close of the village of Chucchurani.

PPD-47 Ol-aug basalt, Barroso Group. E flank of 
Cerro Chucchurani, very close to the village of Chucchurani.

82 PPD-48 Biot rhyolite, Barroso Group. N part of Pampa Amaruybe.

PPD-56 Ol-aug basalt, Barroso Group. On NW flank of Cerro Huancarama.

83 PPD-101 Aug andesite, Barroso Group. NW flank of Cerro Huacarama.

84 PPD-108 $\mathrm{Hb}$ (?)-ol andesite, Barroso Group. N flank of Cerro Marampata. $4 \mathrm{~km} \mathrm{SW}$ of Upahuacho.

85 A-100 Biot(?)-hb andesite, Barroso Group. 0.5 $\mathrm{km} \mathrm{N}$ of Satica.

A-107 Opacite dacite, Barroso Group. $0.3 \mathrm{~km} \mathrm{~S}$ of A-100.

86 A-113 Aphyric basaltic andesite, Barroso Group (?). Anchochuasi, on E bank of Rio Vinchos, near Anchochuasi.

A-116 Biotite rhyolite, welded tuff, Senca Group. $1 \mathrm{~km} \mathrm{~N}$ of Ocayhuacancha, $3 \mathrm{~km}$ SW of Anchachuasi.

87 HPA-54 Oliv(?)-aug-hy andesite, Barroso Group. $1 \mathrm{~km} \mathrm{NW}$ of Quispicancha. E flank of Cerro Chaupiorcco.

\section{APPENDIX 2}

Major element compositions of the volcanic rocks in southern Peru. Total $\mathrm{Fe}$ expressed as $\mathrm{Fe}_{2} \mathrm{O}_{3}$. Numbers refer to those in APPENDIX 1.

\begin{tabular}{lrrrrrrrrrr}
\multicolumn{1}{c}{ No. } & \multicolumn{1}{c}{1} & \multicolumn{1}{c}{2} & \multicolumn{1}{c}{3} & \multicolumn{1}{c}{4} & \multicolumn{1}{c}{5} & \multicolumn{1}{c}{6} & \multicolumn{1}{c}{7} & \multicolumn{1}{c}{8} & \multicolumn{1}{c}{9} & 10 \\
$\mathrm{SiO}_{2}$ & 69.06 & 61.54 & 60.43 & 58.44 & 60.68 & 60.45 & 60.92 & 62.59 & 58.40 & 57.64 \\
$\mathrm{TiO}_{2}$ & 0.45 & 0.71 & 0.70 & 0.96 & 0.88 & 0.94 & 0.90 & 0.82 & 0.99 & 1.07 \\
$\mathrm{Al}_{2} \mathrm{O}_{3}$ & 16.05 & 17.92 & 18.32 & 19.18 & 18.06 & 17.96 & 17.53 & 17.17 & 18.79 & 17.35 \\
$\mathrm{Fe}_{2} \mathrm{O}_{3}$ & 3.28 & 5.84 & 6.21 & 6.52 & 6.36 & 6.44 & 6.65 & 5.18 & 7.00 & 7.48 \\
$\mathrm{MnO}$ & 0.02 & 0.09 & 0.13 & 0.09 & 0.09 & 0.09 & 0.09 & 0.07 & 0.09 & 0.09 \\
$\mathrm{MgO}$ & 0.97 & 2.50 & 2.59 & 2.73 & 2.54 & 2.42 & 2.53 & 2.62 & 2.60 & 4.16 \\
$\mathrm{CaO}$ & 2.66 & 5.21 & 5.60 & 6.14 & 4.96 & 5.03 & 5.36 & 4.65 & 5.55 & 6.49 \\
$\mathrm{Na}_{2} \mathrm{O}$ & 3.37 & 3.64 & 3.43 & 3.48 & 3.39 & 3.58 & 2.98 & 3.79 & 3.76 & 3.13 \\
$\mathrm{~K}_{2} \mathrm{O}$ & 4.05 & 2.36 & 2.40 & 2.23 & 2.80 & 2.81 & 2.88 & 2.91 & 2.56 & 2.34 \\
$\mathrm{P}_{2} \mathrm{O}_{5}$ & 0.09 & 0.18 & 0.18 & 0.24 & 0.25 & 0.29 & 0.17 & 0.21 & 0.26 & 0.24
\end{tabular}

\begin{tabular}{lrrrrrrrrrr} 
No. & \multicolumn{1}{c}{11} & \multicolumn{1}{c}{12} & \multicolumn{1}{c}{13} & \multicolumn{1}{c}{14} & \multicolumn{1}{c}{15} & 16 & \multicolumn{1}{c}{17} & \multicolumn{1}{c}{18} & \multicolumn{1}{c}{19} & \multicolumn{1}{c}{20} \\
$\mathrm{SiO}_{2}$ & 54.07 & 63.00 & 60.76 & 68.54 & 75.22 & 63.00 & 64.47 & 57.82 & 58.20 & 56.58 \\
$\mathrm{TiO}_{2}$ & 1.35 & 0.68 & 0.91 & 0.43 & 0.20 & 0.73 & 0.80 & 0.87 & 1.37 & 1.21 \\
$\mathrm{Al}_{2} \mathrm{O}_{3}$ & 17.04 & 18.16 & 17.08 & 16.46 & 14.40 & 17.13 & 16.18 & 17.85 & 17.47 & 17.81 \\
$\mathrm{Fe}_{2} \mathrm{O}_{3}$ & 8.72 & 5.43 & 6.31 & 3.34 & 1.10 & 5.44 & 4.85 & 6.87 & 6.73 & 7.52 \\
$\mathrm{MnO}$ & 0.11 & 0.08 & 0.07 & 0.05 & 0.06 & 0.06 & 0.05 & 0.10 & 0.07 & 0.09 \\
$\mathrm{MgO}$ & 5.11 & 1.45 & 3.28 & 1.12 & 0.35 & 2.37 & 2.22 & 3.77 & 2.74 & 3.57 \\
$\mathrm{CaO}$ & 7.90 & 4.11 & 5.28 & 2.78 & 0.92 & 4.69 & 3.83 & 6.66 & 5.66 & 6.72 \\
$\mathrm{Na}_{2} \mathrm{O}$ & 3.52 & 3.87 & 3.56 & 3.15 & 3.45 & 3.60 & 3.83 & 3.63 & 4.57 & 4.02 \\
$\mathrm{~K}_{2} \mathrm{O}$ & 1.83 & 3.01 & 2.53 & 4.04 & 4.29 & 2.79 & 3.55 & 2.21 & 2.70 & 2.11 \\
$\mathrm{P}_{2} \mathrm{O}_{5}$ & 0.35 & 0.22 & 0.23 & 0.08 & 0.03 & 0.19 & 0.22 & 0.23 & 0.50 & 0.37 \\
& & & & & & & & & & \\
$\mathrm{No}$ & 21 & 22 & 23 & 24 & 25 & 16 & 27 & 28 & 29 & 30 \\
$\mathrm{SiO}_{2}$ & 57.93 & 54.99 & 59.39 & 67.61 & 57.54 & 67.64 & 63.54 & 59.11 & 56.73 & 64.85 \\
$\mathrm{TiO}_{2}$ & 1.10 & 1.50 & 1.11 & 0.54 & 1.36 & 0.83 & 0.94 & 1.15 & 1.30 & 0.80 \\
$\mathrm{Al}_{2} \mathrm{O}_{3}$ & 17.08 & 17.28 & 17.74 & 17.71 & 17.45 & 14.67 & 16.39 & 17.47 & 17.69 & 16.76 \\
$\mathrm{Fe}_{2} \mathrm{O}_{3}$ & 6.55 & 8.39 & 6.40 & 2.63 & 7.23 & 4.71 & 5.06 & 6.33 & 7.49 & 4.52 \\
$\mathrm{MnO}$ & 0.08 & 0.10 & 0.06 & 0.02 & 0.07 & 0.05 & 0.07 & 0.06 & 0.06 & 0.06 \\
$\mathrm{MgO}_{\mathrm{CaO}}$ & 4.00 & 4.60 & 2.50 & 0.50 & 3.15 & 1.77 & 1.97 & 2.63 & 3.95 & 1.50 \\
$\mathrm{Na}_{2} \mathrm{O}$ & 6.48 & 6.80 & 4.82 & 2.29 & 5.77 & 4.15 & 4.21 & 5.64 & 6.64 & 3.69 \\
$\mathrm{~K}_{2} \mathrm{O}$ & 3.98 & 3.73 & 4.35 & 3.73 & 4.38 & 3.15 & 4.36 & 4.47 & 3.95 & 3.92 \\
$\mathrm{P}_{2} \mathrm{O}_{5}$ & 2.38 & 2.13 & 3.17 & 4.88 & 2.55 & 2.69 & 3.11 & 2.70 & 1.88 & 3.64 \\
& 0.41 & 0.47 & 0.44 & 0.08 & 0.49 & 0.34 & 0.34 & 0.45 & 0.31 & 0.27
\end{tabular}




\begin{tabular}{lr}
\multicolumn{1}{c}{ No. } & \multicolumn{1}{c}{31} \\
$\mathrm{SiO}_{2}$ & 63.85 \\
$\mathrm{TiO}_{2}$ & 0.83 \\
$\mathrm{Al}_{2} \mathrm{O}_{3}$ & 17.64 \\
$\mathrm{Fe}_{2} \mathrm{O}_{3}$ & 4.55 \\
$\mathrm{MnO}$ & 0.06 \\
$\mathrm{MgO}$ & 1.76 \\
$\mathrm{CaO}$ & 3.61 \\
$\mathrm{Na}_{2} \mathrm{O}$ & 3.70 \\
$\mathrm{~K}_{2} \mathrm{O}$ & 3.72 \\
$\mathrm{P}_{2} \mathrm{O}_{5}$ & 0.28
\end{tabular}

\begin{tabular}{rr}
\multicolumn{1}{c}{32} & \multicolumn{1}{c}{33} \\
55.82 & 60.17 \\
1.65 & 1.10 \\
17.59 & 17.25 \\
8.38 & 6.13 \\
0.09 & 0.06 \\
3.48 & 2.75 \\
6.36 & 5.08 \\
4.19 & 4.08 \\
1.91 & 3.01 \\
0.53 & 0.36
\end{tabular}

\begin{tabular}{rrr}
\multicolumn{1}{c}{34} & \multicolumn{1}{c}{35} & \multicolumn{1}{c}{36} \\
56.83 & 61.65 & 63.38 \\
1.33 & 0.93 & 0.88 \\
18.06 & 17.19 & 16.97 \\
7.33 & 5.68 & 5.10 \\
0.08 & 0.06 & 0.06 \\
3.34 & 2.57 & 1.99 \\
5.91 & 4.70 & 4.07 \\
4.43 & 3.91 & 4.11 \\
2.24 & 3.06 & 3.18 \\
0.46 & 0.25 & 0.26
\end{tabular}

37
62.21
0.93
16.95
5.45
0.06
2.34
4.51
4.17
3.10
0.28

38
61.25
0.85
17.17
5.98
0.07
2.98
5.15
3.86
2.48
0.20

\begin{tabular}{rr}
\multicolumn{1}{c}{39} & \multicolumn{1}{c}{40} \\
60.41 & 59.20 \\
0.90 & 1.14 \\
17.07 & 15.48 \\
6.54 & 6.19 \\
0.08 & 0.08 \\
2.88 & 5.29 \\
5.89 & 4.97 \\
3.77 & 2.76 \\
2.27 & 4.45 \\
0.19 & 0.44
\end{tabular}

\begin{tabular}{lr}
\multicolumn{1}{c}{ No. } & \multicolumn{1}{c}{41} \\
$\mathrm{SiO}_{2}$ & 56.52 \\
$\mathrm{TiO}_{2}$ & 1.32 \\
$\mathrm{Al}_{2} \mathrm{O}_{3}$ & 15.62 \\
$\mathrm{Fe}_{2} \mathrm{O}_{3}$ & 7.07 \\
$\mathrm{MnO}$ & 0.09 \\
$\mathrm{MgO}$ & 6.18 \\
$\mathrm{CaO}$ & 5.81 \\
$\mathrm{Na}_{2} \mathrm{O}$ & 2.62 \\
$\mathrm{~K}_{2} \mathrm{O}$ & 4.24 \\
$\mathrm{P}_{2} \mathrm{O}_{5}$ & 0.52
\end{tabular}

42
60.83
1.06
15.87
5.87
0.07
4.68
4.34
2.63
4.27
0.38

\begin{tabular}{rr}
\multicolumn{1}{c}{43} & \multicolumn{1}{c}{44} \\
63.73 & 59.48 \\
0.85 & 1.49 \\
17.32 & 16.88 \\
4.62 & 7.21 \\
0.06 & 0.11 \\
2.35 & 2.43 \\
4.21 & 4.74 \\
2.61 & 3.55 \\
3.97 & 3.58 \\
0.29 & 0.53
\end{tabular}

\begin{tabular}{r}
\multicolumn{1}{c}{45} \\
54.10 \\
1.94 \\
16.45 \\
9.18 \\
0.08 \\
4.58 \\
6.65 \\
3.17 \\
3.12 \\
0.74
\end{tabular}

46
54.97
1.94
16.11
8.53
0.12
4.07
6.56
3.68
3.22
0.79

\begin{tabular}{r}
\multicolumn{1}{c}{47} \\
53.83 \\
1.84 \\
15.51 \\
8.81 \\
0.12 \\
5.75 \\
7.05 \\
3.41 \\
2.97 \\
0.71
\end{tabular}

48
54.18
1.88
15.55
9.35
0.13
5.43
6.60
3.23
3.06
0.59

\begin{tabular}{rr}
\multicolumn{1}{c}{49} & \multicolumn{1}{c}{50} \\
54.69 & 62.88 \\
2.52 & 0.87 \\
14.82 & 17.17 \\
9.41 & 6.29 \\
0.11 & 0.05 \\
4.43 & 1.36 \\
6.68 & 4.61 \\
3.08 & 3.28 \\
3.29 & 3.29 \\
0.97 & 0.19
\end{tabular}

\begin{tabular}{lr}
\multicolumn{1}{c}{ No. } & \multicolumn{1}{c}{51} \\
$\mathrm{SiO}_{2}$ & 62.25 \\
$\mathrm{TiO}_{2}$ & 0.91 \\
$\mathrm{Al}_{2} \mathrm{O}_{3}$ & 17.09 \\
$\mathrm{Fe}_{2} \mathrm{O}_{3}$ & 6.32 \\
$\mathrm{MnO}$ & 0.08 \\
$\mathrm{MgO}$ & 2.25 \\
$\mathrm{CaO}$ & 4.73 \\
$\mathrm{Na} 2 \mathrm{O}$ & 2.83 \\
$\mathrm{~K}_{2} \mathrm{O}$ & 3.33 \\
$\mathrm{P}_{2} \mathrm{O}_{5}$ & 0.20
\end{tabular}

$\begin{array}{rr}52 & 53 \\ 49.78 & 61.01 \\ 1.39 & 1.38 \\ 13.31 & 16.40 \\ 8.62 & 6.33 \\ 0.15 & 0.06 \\ 10.44 & 2.86 \\ 8.48 & 4.19 \\ 2.87 & 3.40 \\ 4.11 & 3.95 \\ 0.84 & 0.42\end{array}$

54
63.76
1.08
16.08
5.35
0.07
2.17
3.49
2.58
5.07
0.35

\begin{tabular}{r}
\multicolumn{1}{c}{55} \\
61.10 \\
0.96 \\
17.62 \\
5.89 \\
0.25 \\
2.42 \\
4.43 \\
3.20 \\
3.81 \\
0.32
\end{tabular}

56
58.94
1.39
16.59
7.51
0.09
2.61
5.52
3.38
3.54
0.45

57
63.65
0.93
16.11
5.51
0.06
2.58
3.83
3.18
3.81
0.33

58
54.94
1.35
15.48
8.06
0.12
6.05
7.31
3.20
2.92
0.56

\begin{tabular}{rr}
\multicolumn{1}{c}{59} & 60 \\
58.31 & 57.69 \\
0.87 & 0.97 \\
18.08 & 17.64 \\
7.08 & 7.77 \\
0.09 & 0.13 \\
3.57 & 3.73 \\
6.12 & 6.47 \\
3.71 & 3.28 \\
2.00 & 2.12 \\
0.18 & 0.20
\end{tabular}

\begin{tabular}{|c|c|}
\hline No. & 61 \\
\hline $\mathrm{SiO}_{2}$ & 59.58 \\
\hline $\mathrm{TiO}_{2}$ & 0.88 \\
\hline $\mathrm{Al}_{2} \mathrm{O}_{3}$ & 17.76 \\
\hline $\mathrm{Fe}_{2} \mathrm{O}_{3}$ & 6.85 \\
\hline $\mathrm{MnO}$ & 0.09 \\
\hline $\mathrm{MgO}$ & 2.99 \\
\hline $\mathrm{CaO}$ & 5.60 \\
\hline $\mathrm{Na}_{2} \mathrm{O}$ & 3.67 \\
\hline $\mathrm{K}_{2} \mathrm{O}$ & 2.38 \\
\hline $\mathrm{P}_{2} \mathrm{O}_{5}$ & 0.20 \\
\hline
\end{tabular}

$\begin{array}{rr}62 & 63 \\ 64.67 & 60.75 \\ 0.70 & 0.64 \\ 16.22 & 18.30 \\ 5.35 & 6.35 \\ 0.09 & 0.08 \\ 2.16 & 2.27 \\ 4.03 & 5.33 \\ 3.36 & 3.36 \\ 3.24 & 2.76 \\ 0.19 & 0.16\end{array}$

\begin{tabular}{rr}
\multicolumn{1}{c}{64} & \multicolumn{1}{c}{65} \\
62.86 & 58.28 \\
0.72 & 0.82 \\
16.73 & 19.07 \\
5.62 & 6.86 \\
0.06 & 0.09 \\
2.61 & 3.07 \\
4.49 & 5.87 \\
3.75 & 3.82 \\
2.98 & 1.89 \\
0.17 & 0.22
\end{tabular}

\begin{tabular}{rr}
\multicolumn{1}{c}{66} & \multicolumn{1}{c}{67} \\
61.74 & 65.63 \\
0.80 & 0.64 \\
17.37 & 16.66 \\
6.01 & 4.35 \\
0.09 & 0.05 \\
2.66 & 1.78 \\
4.92 & 3.56 \\
3.70 & 4.01 \\
2.52 & 3.15 \\
0.19 & 0.17
\end{tabular}

68
60.66
0.76
17.46
6.14
0.08
3.26
5.43
3.76
2.28
0.17

\begin{tabular}{rr}
69 & \multicolumn{1}{c}{70} \\
61.41 & 61.92 \\
0.93 & 0.62 \\
16.46 & 17.44 \\
6.29 & 5.88 \\
0.08 & 0.08 \\
3.05 & 2.54 \\
4.86 & 4.93 \\
3.80 & 3.28 \\
2.87 & 3.16 \\
0.24 & 0.14
\end{tabular}

\begin{tabular}{lrrrrrrrrrr}
\multicolumn{1}{c}{$\mathrm{No}$} & \multicolumn{1}{c}{71} & \multicolumn{1}{c}{72} & \multicolumn{1}{c}{73} & \multicolumn{1}{c}{74} & \multicolumn{1}{c}{75} & \multicolumn{1}{c}{76} & \multicolumn{1}{c}{77} & \multicolumn{1}{c}{78} & \multicolumn{1}{c}{79} & \multicolumn{1}{c}{80} \\
$\mathrm{SiO}_{2}$ & 77.01 & 60.60 & 63.77 & 61.88 & 61.94 & 67.91 & 57.34 & 64.36 & 58.57 & 56.05 \\
$\mathrm{TiO}_{2}$ & 0.08 & 0.77 & 0.71 & 0.86 & 0.96 & 0.48 & 0.86 & 0.80 & 0.82 & 0.99 \\
$\mathrm{Al}_{2} \mathrm{O}_{3}$ & 13.51 & 16.52 & 15.94 & 16.76 & 17.04 & 16.20 & 18.98 & 16.68 & 17.55 & 17.17 \\
$\mathrm{Fe}_{2} \mathrm{O}_{3}$ & 0.53 & 6.47 & 5.33 & 5.87 & 6.33 & 3.24 & 7.99 & 5.06 & 7.41 & 7.87 \\
$\mathrm{MnO}$ & 0.20 & 0.12 & 0.05 & 0.07 & 0.08 & 0.08 & 0.10 & 0.06 & 0.12 & 0.11 \\
$\mathrm{MgO}$ & 0.13 & 3.54 & 2.80 & 2.33 & 2.00 & 0.78 & 2.43 & 2.10 & 3.20 & 4.62 \\
$\mathrm{CaO}$ & 0.32 & 5.31 & 4.45 & 4.19 & 4.45 & 2.10 & 6.51 & 3.97 & 6.56 & 7.44 \\
$\mathrm{Na}{ }_{2} \mathrm{O}$ & 3.82 & 3.26 & 2.86 & 3.17 & 3.62 & 4.00 & 3.36 & 3.48 & 3.19 & 3.06 \\
$\mathrm{~K}_{2} \mathrm{O}$ & 4.39 & 3.24 & 3.91 & 4.61 & 3.27 & 5.13 & 2.17 & 3.29 & 2.41 & 2.46 \\
$\mathrm{P}_{2} \mathrm{O}_{5}$ & 0.00 & 0.17 & 0.18 & 0.27 & 0.31 & 0.09 & 0.26 & 0.2 1 & 0.18 & 0.23
\end{tabular}




\begin{tabular}{lrrrrrrr}
\multicolumn{1}{c}{$\mathrm{No}}$. & \multicolumn{1}{c}{81} & \multicolumn{1}{c}{82} & \multicolumn{1}{c}{83} & \multicolumn{1}{c}{84} & \multicolumn{1}{c}{85} & \multicolumn{1}{c}{86} & \multicolumn{1}{c}{87} \\
$\mathrm{SiO}_{2}$ & 51.68 & 74.14 & 54.92 & 60.04 & 65.46 & 52.22 & 55.92 \\
$\mathrm{TiO}_{2}$ & 2.01 & 0.25 & 1.35 & 0.98 & 0.82 & 1.90 & 1.36 \\
$\mathrm{Al}_{2} \mathrm{O}_{3}$ & 16.33 & 14.21 & 16.73 & 17.11 & 17.34 & 17.58 & 17.43 \\
$\mathrm{Fe}_{2} \mathrm{O}_{3}$ & 10.08 & 1.49 & 7.36 & 6.41 & 4.15 & 11.41 & 8.09 \\
$\mathrm{MnO}$ & 0.12 & 0.10 & 0.11 & 0.10 & 0.02 & 0.23 & 0.08 \\
$\mathrm{MgO}$ & 6.53 & 0.46 & 3.80 & 2.95 & 1.03 & 5.96 & 4.25 \\
$\mathrm{CaO}$ & 7.89 & 1.08 & 7.32 & 5.97 & 3.48 & 4.17 & 6.83 \\
$\mathrm{Na}_{2} \mathrm{O}$ & 3.27 & 3.84 & 3.42 & 3.72 & 4.33 & 3.68 & 3.38 \\
$\mathrm{~K}_{2} \mathrm{O}$ & 1.59 & 4.36 & 4.03 & 2.50 & 3.14 & 2.06 & 2.31 \\
$\mathrm{P}_{2} \mathrm{O}_{5}$ & 0.50 & 0.06 & 0.97 & 0.23 & 0.24 & 0.77 & 0.35
\end{tabular}

